\section{1-Methylcyclopropene Concentration and Timing of Postharvest Application Alters the Ripening of 'Mclntosh' Apples during Storage}

\author{
Jennifer R. DeEll ${ }^{1,4}$, Jennifer T. Ayres ${ }^{2}$, and Dennis P. Murr ${ }^{3}$
}

AdDitional Index wORDs. Malus $\times$ domestica, SmartFresh, 1-MCP, ethylene, firmness, storage disorders

SumMARY. This study evaluated the effects of 1-methylcyclopropene (1-MCP) concentration ( 1000 vs. $625 \mathrm{ppb})$ and treatment delays $(3,7$, and 10 days after harvest) on the ripening and incidence of storage disorders in 'McIntosh' apples from three harvest times in 2004. Apples were stored in air at $0{ }^{\circ} \mathrm{C}$ to $1{ }^{\circ} \mathrm{C}$ for 3 and 6 months or in controlled atmosphere (CA) storage at $3{ }^{\circ} \mathrm{C}$ for 6 and 9 months. Apples treated with 1-MCP and held in air or CA storage were firmer than those not treated, but this difference in firmness was less with later harvests, more delay before 1-MCP treatment, and longer storage time. Apples treated with $1000 \mathrm{ppb} 1-\mathrm{MCP}$ were often firmer than those treated with $625 \mathrm{ppb}$ after 6 months of storage and/or 7 days at $22{ }^{\circ} \mathrm{C}$. Ethylene and carbon dioxide $\left(\mathrm{CO}_{2}\right)$ production were reduced in apples treated with 1-MCP, especially in fruit from the first harvest and those treated 3 days after harvest. Fruit treated with $1000 \mathrm{ppb}$ 1-MCP showed a slower increase in ethylene production than those treated with $625 \mathrm{ppb}$ during 14 days at $22{ }^{\circ} \mathrm{C}$ after storage. $\mathrm{CO}_{2}$ production was the lowest in 'McIntosh' apples treated with $1000 \mathrm{ppb} 1$-MCP 3 days after harvest, but fruit treated with $625 \mathrm{ppb}$ also exhibited lower respiration than those not treated. Storage disorders were most prevalent in 'McIntosh' apples stored for 6 months in air at $0^{\circ} \mathrm{C}$ to $1{ }^{\circ} \mathrm{C}$, whereas fruit from the first harvest treated with 1-MCP 3 days after harvest developed the fewest disorders. 1-MCP reduced the incidence of superficial scald, flesh browning, core browning, and senescent breakdown, while 1-MCP concentration and treatment delay had varying effects. This research has provided the basis for Canadian registration of SmartFresh ${ }^{\mathrm{SM}}$ use on apples at $1000 \mathrm{ppb} 1-\mathrm{MCP}$ and for the requirement that treatment be within 3 days of harvest.

1 -Methylcyclopropene (1-MCP) inhibits the action of ethylene and, therefore, it has the unique ability to maintain quality and extend the shelf-life of many fresh fruit and vegetables. The postharvest gaseous application of 1-MCP has been shown to improve many physiological characteristics of apples, such as reduced ethylene production and respiration, enhanced fruit firmness and acidity retention, and reduced peel greasiness and various physiological disorders (Blankenship and Dole, 2003; DeEll et al., 2007; Fan et al., 1999a, 1999b; Watkins, 2006).

\footnotetext{
We gratefully acknowledge the support of AgroFresh Inc., Canadian Horticultural Council, Norfolk Fruit Growers' Association, Lingwood Farms Ltd., University of Guelph, and the Ontario Ministry of Agriculture, Food, and Rural Affairs during the course of this research

${ }^{1}$ Ontario Ministry of Agriculture, Food and Rural Affairs, Simcoe, Ontario, Canada N3Y 4N5

${ }^{2}$ Research Assistant, University of Western Ontario, London, Ontario, Canada N6A 3K7

${ }^{3}$ Department of Plant Agriculture, University of Guelph, Guelph, Ontario, Canada NIG 2W1

${ }^{4}$ Corresponding author. E-mail: Jennifer.DeEll@
} ontario.ca.
1-MCP affects the incidence of storage disorders in a variety of ways, depending on apple cultivar and storage regime. Superficial scald is generally reduced by 1-MCP (DeEll et al., 2002; Fan et al., 1999b; Moran, 2006; Rupasinghe et al., 2000; Watkins et al., 2000), as is peel greasiness (Fan et al., 1999b; Watkins and Nock, 2005) and senescent breakdown (DeLong et al., 2004; Watkins et al., 2000). There is often no effect of l-MCP on internal browning in 'Empire' apples (DeEll et al., 2007;
Fawbush et al., 2008; Watkins and Nock, 2005). Core browning is reduced by 1-MCP in 'McIntosh' apples held in air storage at $0.5^{\circ} \mathrm{C}$ (Watkins et al., 2000), but is increased in 'Delicious' apples stored long-term in controlled atmosphere (CA) (DeEll et al., 2007). 1-MCP also increases susceptibility to external $\mathrm{CO}_{2}$ injury in 'Empire' and McIntosh' apples (DeEll et al., 2003; Fawbush et al., 2008). Watkins (2007) recently reviewed the effect of 1-MCP on the development of physiological storage disorders in horticultural crops.

There are many factors that can influence the response of apples to 1-MCP. Each cultivar tends to behave differently and responses often vary with storage conditions (Bai et al., 2005; DeEll et al., 2005a; Fan et al., 1999a, 1999b; Watkins et al., 2000). 1-MCP treatment temperature is important when application is less than $9 \mathrm{~h}$ (DeEll et al., 2002), whereas temperature has little effect in the case of 24-h treatments (Watkins and Nock, 2005). A dose response of l-MCP has been found in some cultivars but not in others (Watkins et al., 2000). Application delays of up to $8 \mathrm{~d}$ can have no effect on 1-MCP efficacy or it can markedly reduce it (Watkins and Nock, 2005).

The commercial formulation of 1-MCP for use on food is SmartFresh $^{\text {SM }}$ (AgroFresh, Spring House, PA). Application in the United States is at a concentration of $1000 \mathrm{ppb} 1$ MCP, whereas in United Kingdom it is $625 \mathrm{ppb}$. Due to the diverse responses of apples to 1-MCP, these concentrations could result in different effects under various conditions. The objectives of this work were to investigate the effects of $1-\mathrm{MCP}$ concentration (1000 vs. $625 \mathrm{ppb})$ and

\begin{tabular}{llll}
\hline $\begin{array}{l}\text { Units } \\
\begin{array}{l}\text { To convert U.S. to SI, } \\
\text { multiply by }\end{array}\end{array}$ & U.S unit & SI unit & $\begin{array}{l}\text { To convert SI to U.S., } \\
\text { multiply by }\end{array}$ \\
\hline 29.5735 & $\mathrm{fl} \mathrm{oz}$ & $\mathrm{mL}$ & 0.0338 \\
0.3048 & $\mathrm{ft}$ & $\mathrm{m}$ & 3.2808 \\
3.7854 & $\mathrm{gal}$ & $\mathrm{L}$ & 0.2642 \\
25.4 & inch(es) & $\mathrm{mm}$ & 0.0394 \\
0.4536 & $\mathrm{lb}$ & $\mathrm{kg}$ & 2.2046 \\
4.4482 & $\mathrm{lbf}$ & $\mathrm{N}$ & 0.2248 \\
1 & $\mathrm{ppb}$ & $\mathrm{nL} \cdot \mathrm{L}^{-1}$ & 1 \\
0.001 & $\mathrm{ppm}$ & $\mathrm{mL} \cdot \mathrm{kg}^{-1}$ & 1000 \\
1 & $\mathrm{ppm}$ & $\mu \mathrm{L} \cdot \mathrm{kg}^{-1}$ & 1 \\
1 & $\mathrm{ppm}$ & $\mu \mathrm{L} \cdot \mathrm{L}^{-1}$ & 1 \\
$\left({ }^{\circ} \mathrm{F}-32\right) \div 1.8$ & ${ }^{\circ} \mathrm{F}$ & ${ }^{\circ} \mathrm{C}$ & $\left(1.8 \times{ }^{\circ} \mathrm{C}\right)+32$ \\
& & &
\end{tabular}


treatment delays after harvest $(3,7$, and $10 \mathrm{~d}$ ) on the ripening and incidence of storage disorders in 'McIntosh' apples from three harvest times. Apples were stored in air at $0{ }^{\circ} \mathrm{C}$ to $1^{\circ} \mathrm{C}$ for 3 and 6 months, as well as in CA storage at $3{ }^{\circ} \mathrm{C}$ for 6 and 9 months.

\section{Materials and methods}

Apple HARVEST. 'McIntosh' apples ('Summerland' strain) were harvested from a mature orchard in Norfolk County, Ontario, on the first (Harvest 1), sixth (Harvest 2), and 1 l th (Harvest 3 ) days of the commercial harvest in 2004. There were 108 boxes of fruit $(\approx 20 \mathrm{~kg}$ each) harvested at each time. All apples were drenched with diphenylamine [1000 ppm a.i. (ShieldBrite; Pace International, Seattle)] and thiabendazole [500 ppm a.i. (Mertect; Syngenta, Wilmington, DE)] at a local commercial packinghouse and then transported to the postharvest physiology laboratory at the University of Guelph.

Postharvest treatments. Apples were cooled overnight at $0{ }^{\circ} \mathrm{C}$ to $1{ }^{\circ} \mathrm{C}$ and held for 3,7 , or $10 \mathrm{~d}$ before treatment with 1-MCP. Boxes from each harvest and holding delay combination were placed in sealed air-tight plastic bags $(6 \mathrm{mil})$ and exposed to 0,625 , or $1000 \mathrm{ppb}$ of 1-MCP (SmartFresh ${ }^{\text {SM }}$ ) for $24 \mathrm{~h}$ at $0{ }^{\circ} \mathrm{C}$ to $1^{\circ} \mathrm{C}$. The $1-\mathrm{MCP}$ concentration was calculated according to the percentage a.i. and release from the SmartFresh ${ }^{S M}$ powder into the free headspace of the sealed bags.

Immediately after treatment with 1-MCP, apples were held in air at $0{ }^{\circ} \mathrm{C}$ to $l^{\circ} \mathrm{C}$ for 3 and 6 months or in standard CA storage [2.5\% oxygen $\left(\mathrm{O}_{2}\right)+2.5 \% \mathrm{CO}_{2}$ for $30 \mathrm{~d}, 4.5 \% \mathrm{CO}_{2}$ thereafter] at $3{ }^{\circ} \mathrm{C}$ for 6 and 9 months. There were three box replicates of apples per treatment and storage combination. In addition, 25 fruit per treatment combination were held at $22{ }^{\circ} \mathrm{C}$ for $14 \mathrm{~d}$ immediately after 1-MCP treatment and were then evaluated as a confirmation test of 1-MCP effectiveness.

The $\mathrm{O}_{2}$ concentration within the CA chambers $(\approx 1000 \mathrm{~L}$ each $)$ was established within 4 to $5 \mathrm{~h}$ of sealing, after flushing with nitrogen $\left(\mathrm{N}_{2}\right)$ until $2.5 \% \mathrm{O}_{2}$ was reached. The $\mathrm{CO}_{2}$ levels were then established gradually
Table 1. Internal ethylene concentration (IEC), starch index, firmness, and soluble solids concentration (SSC) of 'McIntosh' apples at harvest.

\begin{tabular}{|c|c|c|c|c|}
\hline & IEC $(p p m)^{z}$ & Starch index $(1-8 \text { scale })^{y}$ & Firmness (lbf $)^{x}$ & SSC (\%) \\
\hline Harvest 1 & 0.06 & 5.0 & 15.4 & 10.8 \\
\hline Harvest 2 & 0.03 & 5.1 & 14.9 & 11.3 \\
\hline Harvest 3 & 0.13 & 6.3 & 14.0 & 10.1 \\
\hline
\end{tabular}

Table 2. Internal ethylene concentration (IEC), firmness, and soluble solids concentration (SSC) of 'McIntosh' apples from three harvests, treated with 1-methylcyclopropene (1-MCP; 0, 625, or $\left.1000 \mathrm{ppb}^{\mathrm{z}}\right) 3,7$, or $10 \mathrm{~d}$ after harvest, and held $14 \mathrm{~d}$ at $22^{\circ} \mathrm{C}\left(71.6^{\circ} \mathrm{F}\right)$ (confirmation test).

\begin{tabular}{|c|c|c|c|}
\hline & $\begin{array}{c}\text { IEC } \\
(\mathrm{ppm})^{\mathrm{y}}\end{array}$ & $\begin{array}{c}\text { Firmness } \\
(\text { lbf })^{x}\end{array}$ & $\begin{array}{c}\text { SSC } \\
(\%)\end{array}$ \\
\hline \multicolumn{4}{|l|}{ Harvest 1} \\
\hline \multicolumn{4}{|c|}{ 1-MCP $3 \mathrm{~d}$ after harvest } \\
\hline $0 \mathrm{ppb}$ & 1,163 & 11.1 & 11.3 \\
\hline $625 \mathrm{ppb}$ & 169 & 15.1 & 11.2 \\
\hline $1,000 \mathrm{ppb}$ & 1 & 15.2 & 11.4 \\
\hline \multicolumn{4}{|c|}{ 1-MCP $7 \mathrm{~d}$ after harvest } \\
\hline $0 \mathrm{ppb}$ & 965 & 11.0 & 10.8 \\
\hline $625 \mathrm{ppb}$ & 339 & 14.9 & 11.1 \\
\hline $1,000 \mathrm{ppb}$ & 94 & 15.0 & 11.1 \\
\hline \multicolumn{4}{|c|}{ 1-MCP $10 \mathrm{~d}$ after harvest } \\
\hline $0 \mathrm{ppb}$ & 860 & 10.6 & 10.8 \\
\hline $625 \mathrm{ppb}$ & 738 & 14.1 & 10.8 \\
\hline $1,000 \mathrm{ppb}$ & 742 & 13.8 & 11.3 \\
\hline \multicolumn{4}{|l|}{ Harvest 2} \\
\hline \multicolumn{4}{|c|}{ 1-MCP $3 \mathrm{~d}$ after harvest } \\
\hline $0 \mathrm{ppb}$ & 856 & 11.2 & 10.9 \\
\hline $625 \mathrm{ppb}$ & 772 & 14.8 & 11.5 \\
\hline $1,000 \mathrm{ppb}$ & 197 & 15.0 & 11.5 \\
\hline \multicolumn{4}{|c|}{ 1-MCP $7 \mathrm{~d}$ after harvest } \\
\hline $0 \mathrm{ppb}$ & 905 & 9.6 & 10.1 \\
\hline $625 \mathrm{ppb}$ & 709 & 12.8 & 11.6 \\
\hline $1,000 \mathrm{ppb}$ & 496 & 13.6 & 11.6 \\
\hline \multicolumn{4}{|c|}{ 1-MCP $10 \mathrm{~d}$ after harvest } \\
\hline $0 \mathrm{ppb}$ & 1,017 & 11.0 & 11.5 \\
\hline $625 \mathrm{ppb}$ & 889 & 13.5 & 11.8 \\
\hline $1,000 \mathrm{ppb}$ & 1,009 & 13.3 & 11.7 \\
\hline \multicolumn{4}{|l|}{ Harvest 3} \\
\hline \multicolumn{4}{|c|}{ 1-MCP $3 \mathrm{~d}$ after harvest } \\
\hline $0 \mathrm{ppb}$ & 776 & 9.6 & 10.2 \\
\hline $625 \mathrm{ppb}$ & 717 & 12.1 & 10.3 \\
\hline $1,000 \mathrm{ppb}$ & 551 & 12.9 & 10.3 \\
\hline \multicolumn{4}{|c|}{ 1-MCP $7 \mathrm{~d}$ after harvest } \\
\hline $0 \mathrm{ppb}$ & 878 & 9.5 & 10.1 \\
\hline $625 \mathrm{ppb}$ & 821 & 11.1 & 10.2 \\
\hline $1,000 \mathrm{ppb}$ & 649 & 11.5 & 10.2 \\
\hline \multicolumn{4}{|c|}{ 1-MCP $10 \mathrm{~d}$ after harvest } \\
\hline $0 \mathrm{ppb}$ & 818 & 9.9 & 9.8 \\
\hline $625 \mathrm{ppb}$ & 747 & 11.1 & 9.7 \\
\hline $1,000 \mathrm{ppb}$ & 779 & 11.4 & 9.9 \\
\hline SE & 80.3 & 0.24 & 0.15 \\
\hline \multirow{3}{*}{ Significance $^{w}$} & $\mathrm{~T} \times \mathrm{M} \times \mathrm{H}^{* *}$ & $\mathrm{~T} \times \mathrm{M}^{* * *}$ & $\mathrm{~T} \times \mathrm{H}^{* * *}$ \\
\hline & & $\mathrm{T} \times \mathrm{H}^{* * *}$ & $M^{* *}$ \\
\hline & & $\mathrm{M} \times \mathrm{H}^{* * *}$ & \\
\hline
\end{tabular}

${ }^{\mathrm{z}} 1 \mathrm{ppb}=1 \mathrm{~nL} \cdot \mathrm{L}^{-1}$.

${ }^{\mathrm{y}} \mathrm{IEC}=$ internal ethylene concentration; $1 \mathrm{ppm}=1 \mu \mathrm{L} \cdot \mathrm{L}^{-1}$

${ }^{x} l \mathrm{lbf}=4.4482 \mathrm{~N}$.

${ }^{\mathrm{w} *},{ }^{* *},{ }^{* *}$ Significant at $P<0.05, P<0.01$, or $P<0.001$, respectively, where $\mathrm{T}=$ treatment time, $\mathrm{M}=1-\mathrm{MCP}$ concentration, and $\mathrm{H}=$ harvest. 
over a 72-h period by stepwise addition of $\mathrm{CO}_{2}$ to the chambers. Gas levels were monitored daily with a gas analyzer (NOVA Analytical Instruments, Hamilton, ON) and adjustments using air, $\mathrm{N}_{2}$, or $\mathrm{CO}_{2}$ were made accordingly so that atmospheres never fluctuated more than $\pm 0.1 \%$.

Maturity and QUality EVALUATIONS. Initial maturity was evaluated on three groups of 10-apple samples from each harvest. Starch content was determined using the Cornell Starch Chart (Blanpied and Silsby, 1992). Apples were cut in half at the equator and were rated on a scale of 1 to 8 , where $1=100 \%$ starch staining and $8=0 \%$ staining. Internal ethylene concentration (IEC) was determined by withdrawing a $3-\mathrm{mL}$ gas sample from the core of each fruit using a syringe and injecting the sample into a gas chromatograph (CP-3800; Varian Canada, Mississauga, $\mathrm{ON}$ ) equipped with a $0.5-\mathrm{mL}$ sample loop, flame ionization detector (FID), and a $15 \mathrm{~m} \times 0.32-\mathrm{mm}$ Restek Rt-SPLOT ${ }^{\mathrm{TM}}$ capillary column (Chromatographic Specialties, Brockville, $\mathrm{ON}$ ). The injector, column, and detector temperatures were $120{ }^{\circ} \mathrm{C}$, $35{ }^{\circ} \mathrm{C}$, and $225{ }^{\circ} \mathrm{C}$, respectively. High-grade helium was used as the carrier gas at a flow rate of $0.37 \mathrm{~mL} \cdot \mathrm{s}^{-1}$ with a typical run time of $2 \mathrm{~min}$. Fruit firmness was determined on opposite sides (blush and green) of each apple after peel removal, using an electronic pressure tester fitted with an $11-\mathrm{mm}$ tip (Lake City Technical Products, Kelowna, BC). Soluble solids concentration (SSC) in the juice expressed during firmness testing was determined using a hand-held temperature-compensated refractometer (Fisher Scientific, Nepean, ON).

Samples of 25 apples from each harvest and 1-MCP treatment combination were held at $22{ }^{\circ} \mathrm{C}$ for $14 \mathrm{~d}$ immediately after 1-MCP application. These fruit were then evaluated as a confirmation test for the 1-MCP treatment. IEC, firmness, and SSC were measured using the methods described above.

After each storage regime, 10 fruit per box replicate from each treatment combination were also measured for firmness after 1 and $7 \mathrm{~d}$ at $22{ }^{\circ} \mathrm{C}$. In addition, the incidence of core browning, internal browning, senescent breakdown, and superficial scald were determined using 25 apples per box replicate from each treatment combination. Incidence was calculated as a percentage of fruit with the disorder, regardless of severity.

E T H Y E N A N D C O 2 PRODUCTION. After each storage regime, a representative 1 to $1.5-\mathrm{kg}$ sample of nine fruit was removed from each treatment combination (three fruit per box rep) and placed in 4.9- $\mathrm{L}$ glass jars. $\mathrm{CO}_{2}$ and ethylene in the headspace of the jars were measured after $1,4,7,11$, and $14 \mathrm{~d}$ at $22{ }^{\circ} \mathrm{C}$. Apples in the jars were aerated with a stream of ethylene-free air for $20 \mathrm{~min}$ and the jars were then sealed gas-tight for $30 \mathrm{~min}$. At this time, a $3-\mathrm{mL}$ gas sample was withdrawn from the headspace of the jar with a syringe inserted through a rubber septum in the lid and the gas sample was analyzed for ethylene as described above. Immediately after injection of the ethylene sample, the headspace was sampled again and analyzed for $\mathrm{CO}_{2}$ by injecting

Table 3. Firmness of 'McIntosh' apples from three harvests treated with 1-methylcyclopropene (1-MCP; 0, 625, or $\left.1000 \mathrm{ppb}^{\mathrm{z}}\right) 3,7$, or $10 \mathrm{~d}$ after harvest, and stored for 3 or 6 months in air at $0^{\circ} \mathrm{C}$ to $1^{\circ} \mathrm{C}\left(32.0^{\circ} \mathrm{F}-33.8^{\circ} \mathrm{F}\right)$. The highest levels of significant effects (interactive) are presented and the data are the means of two evaluations after storage [ 1 and $7 \mathrm{~d}$ at $\left.22^{\circ} \mathrm{C}\left(71.6^{\circ} \mathrm{F}\right)\right]$.

\begin{tabular}{|c|c|c|c|}
\hline & \multicolumn{3}{|c|}{ Firmness $(\mathrm{lbf})^{\mathrm{y}}$} \\
\hline & \multicolumn{3}{|c|}{ 1-MCP concentration (ppb) } \\
\hline & $\mathbf{0}$ & 625 & 1000 \\
\hline \multicolumn{4}{|l|}{3 Months } \\
\hline Harvest 1 & 12.3 & 14.0 & 14.1 \\
\hline Harvest 2 & 11.8 & 13.1 & 13.3 \\
\hline Harvest 3 & 12.1 & 13.0 & 13.3 \\
\hline \multicolumn{4}{|l|}{6 Months } \\
\hline Harvest 1 & 10.6 & 12.7 & 13.2 \\
\hline Harvest 2 & 10.3 & 11.1 & 11.0 \\
\hline Harvest 3 & 10.0 & 11.3 & 11.9 \\
\hline \multicolumn{4}{|l|}{$\mathrm{SE}=0.17$} \\
\hline Significance ${ }^{\mathrm{x}}$ & $\mathrm{M} \times \mathrm{H} \times \mathrm{O}^{*}$ & & \\
\hline \multicolumn{4}{|l|}{3 Months } \\
\hline \multicolumn{4}{|c|}{ Time from harvest to $1-\mathrm{MCP}$ treatment $(\mathrm{d})$} \\
\hline 3 & 12.0 & 13.5 & 13.9 \\
\hline 7 & 12.1 & 13.3 & 13.5 \\
\hline 10 & 12.2 & 13.4 & 13.3 \\
\hline \multicolumn{4}{|l|}{6 Months } \\
\hline \multicolumn{4}{|c|}{ Time from harvest to 1 -MCP treatment (d) } \\
\hline 3 & 10.5 & 11.9 & 11.9 \\
\hline 7 & 10.0 & 11.5 & 12.4 \\
\hline 10 & 10.4 & 11.7 & 11.8 \\
\hline \multicolumn{4}{|l|}{$\mathrm{SE}=0.17$} \\
\hline Significance $^{\mathrm{x}}$ & $\mathrm{T} \times \mathrm{M} \times \mathrm{O}^{*}$ & & \\
\hline
\end{tabular}

another 3-mL gas sample into an ADC IR gas analyzer (Nortech Control Equipment, Etobicoke, $\mathrm{ON})$.

Statistical analyses. Data from air- and CA-stored fruit were analyzed separately, using the analysis of variance procedure of Genstat 5 (Payne, 2000). Within each storage type, the effects of harvest time (Harvests 1-3), delay in 1-MCP application $(3,7$, and $10 \mathrm{~d})$, 1-MCP concentration $(0,625$, and 1000 $\mathrm{ppb}$ ), storage duration (3 and 6 months in air or 6 and 9 months in CA), and days at $22{ }^{\circ} \mathrm{C}(1$ and $7 \mathrm{~d})$ were determined. Sources of variation 0.05 .

\section{Results and discussion}

'McIntosh' apples from the first two harvests were of optimum maturity for long-term storage (Table 1 ). IEC was less than 1 ppm and the starch index was between 5 and 6 , which is the recommended range were considered significant at $P \leq$ 
for CA storage of 'McIntosh' (Blanpied and Silsby, 1992). Apples from Harvest 3 had an average starch index higher than 6 and thus were a little overmature for successful longterm storage. Fruit firmness ranged from $15.4 \mathrm{lbf}$ for the first harvest to $14.0 \mathrm{lbf}$ for the third harvest (Table 1).

After 1-MCP treatments and $14 \mathrm{~d}$ at $22{ }^{\circ} \mathrm{C}$, 'McIntosh' apples from the first harvest treated $3 \mathrm{~d}$ after harvest had the lowest IEC and highest fruit firmness (Table 2). These quality benefits were gradually reduced with later harvests and more delay before 1-MCP treatment. The higher concentration of 1-MCP $(1000 \mathrm{ppb})$ resulted in less IEC but not always greater firmness in fruit from the first two harvests when treated within $7 \mathrm{~d}$ compared with $625 \mathrm{ppb}$. Overall, these results confirm that the 1-MCP applications were effective.

Apples treated with 1-MCP and held in air storage for 3 or 6 months at $0{ }^{\circ} \mathrm{C}$ to $1^{\circ} \mathrm{C}$ or in CA storage for 6 or 9 months at $3{ }^{\circ} \mathrm{C}$ were firmer than those not treated (Tables 3 and 4). However, this difference in firmness was less with later harvests, more delay before 1-MCP treatment, and longer storage time. Apples treated with $1000 \mathrm{ppb}$ l-MCP were firmer than those treated with $625 \mathrm{ppb}$ in certain situations. Fruit from Harvest 3 or those treated with 1-MCP $7 \mathrm{~d}$ after harvest were slightly firmer with 1000 than 625 ppb after 6 months of air storage (Table 3). 'McIntosh' apples from the first two harvests treated $3 \mathrm{~d}$ after harvest and held in CA storage were also firmer with 1000 than $625 \mathrm{ppb}$ 1-MCP (Table 4). This additional firmness benefit with $1000 \mathrm{ppb}$ was more prominent after 6 months of CA or $7 \mathrm{~d}$ at $22^{\circ} \mathrm{C}$.

Improved firmness retention is a well-documented response of apples to 1-MCP (Bai et al., 2005; DeEll et al., 2007; Watkins et al., 2000; Watkins and Nock, 2005). The results of this study show the importance of 1-MCP concentration and time between harvest and application. Since a specific amount of 1-MCP is used for a range of commercial room sizes (SmartFresh ${ }^{\text {SM }}$ application by AgroFresh), in certain commercial situations the concentration of 1-MCP can be less than the expected $1000 \mathrm{ppb}$, and for cultivars like
'McIntosh' this can reduce the beneficial effect on firmness. The SmartFresh $^{\text {SM }}$ label in Canada states that application must be made within $3 \mathrm{~d}$ of harvest, whereas the window for treatment in the United States is $7 \mathrm{~d}$. Firmness retention in 'McIntosh' apples due to 1-MCP would be better with application closer to harvest, as indicated by the results of this study.

Ethylene production was reduced in apples treated with 1-MCP

Table 4. Firmness of 'McIntosh' apples from three harvests treated with 1-methylcyclopropene (1-MCP; 0,625 , or $\left.1000 \mathrm{ppb}^{\mathrm{z}}\right) 3,7$, or $10 \mathrm{~d}$ after harvest, stored for 6 or 9 months in $\mathrm{CA}$ at $3{ }^{\circ} \mathrm{C}\left(37.4^{\circ} \mathrm{F}\right)$, and held 1 or $7 \mathrm{~d}$ at $22^{\circ} \mathrm{C}\left(71.6^{\circ} \mathrm{F}\right)$. The highest levels of significant effects (interactive) are presented.

\begin{tabular}{|c|c|c|c|}
\hline & \multicolumn{3}{|c|}{ Firmness $(\mathrm{lbf})^{\mathrm{y}}$} \\
\hline & \multicolumn{3}{|c|}{ Time from harvest to l-MCP treatment (d) } \\
\hline & 3 & 7 & 10 \\
\hline \multicolumn{4}{|l|}{ Harvest 1} \\
\hline $0 \mathrm{ppb} 1-\mathrm{MCP}$ & 12.9 & 12.0 & 12.1 \\
\hline $625 \mathrm{ppb}$ & 13.6 & 13.4 & 12.6 \\
\hline $1,000 \mathrm{ppb}$ & 14.4 & 13.1 & 12.4 \\
\hline \multicolumn{4}{|l|}{ Harvest 2} \\
\hline 0 ppb l-MCP & 12.0 & 11.5 & 11.5 \\
\hline $625 \mathrm{ppb}$ & 12.5 & 12.5 & 12.5 \\
\hline $1,000 \mathrm{ppb}$ & 12.9 & 12.5 & 12.4 \\
\hline \multicolumn{4}{|l|}{ Harvest 3} \\
\hline $0 \mathrm{ppb} 1-\mathrm{MCP}$ & 11.8 & 11.7 & 11.5 \\
\hline $625 \mathrm{ppb}$ & 12.4 & 12.2 & 12.2 \\
\hline $1,000 \mathrm{ppb}$ & 12.2 & 12.4 & 12.0 \\
\hline \multicolumn{4}{|l|}{$\mathrm{SE}=0.10$} \\
\hline Significance $^{\mathrm{x}}$ & $\mathrm{T} \times \mathrm{M} \times \mathrm{H}^{* * *}$ & & \\
\hline \multicolumn{4}{|l|}{$6 \mathrm{mo.}$} \\
\hline 0 ppb l-MCP & 12.6 & 12.3 & 12.0 \\
\hline $625 \mathrm{ppb}$ & 13.4 & 13.1 & 12.9 \\
\hline $1,000 \mathrm{ppb}$ & 13.9 & 13.3 & 12.8 \\
\hline \multicolumn{4}{|l|}{9 mo. } \\
\hline 0 ppb l-MCP & 11.9 & 11.2 & 11.4 \\
\hline $625 \mathrm{ppb}$ & 12.3 & 12.3 & 12.0 \\
\hline $1,000 \mathrm{ppb}$ & 12.5 & 12.0 & 11.7 \\
\hline \multicolumn{4}{|l|}{$\mathrm{SE}=0.08$} \\
\hline Significance $^{\mathrm{x}}$ & $\mathrm{T} \times \mathrm{M} \times \mathrm{O}^{*}$ & & \\
\hline \multicolumn{4}{|l|}{$\mathrm{ld}$ at $22^{\circ} \mathrm{C}$} \\
\hline 0 ppb l-MCP & 13.5 & 12.5 & 12.5 \\
\hline $625 \mathrm{ppb}$ & 14.3 & 13.9 & 13.4 \\
\hline $1,000 \mathrm{ppb}$ & 14.4 & 13.9 & 13.1 \\
\hline \multicolumn{4}{|l|}{$7 \mathrm{~d}$ at $22^{\circ} \mathrm{C}$} \\
\hline 0 ppb l-MCP & 11.0 & 10.9 & 10.9 \\
\hline $625 \mathrm{ppb}$ & 11.3 & 11.5 & 11.4 \\
\hline $1,000 \mathrm{ppb}$ & 12.0 & 11.5 & 11.4 \\
\hline \multicolumn{4}{|l|}{$\mathrm{SE}=0.08$} \\
\hline Significance $^{\mathrm{x}}$ & $\mathrm{T} \times \mathrm{M} \times \mathrm{D}^{*}$ & & \\
\hline
\end{tabular}

and held in air storage at $0{ }^{\circ} \mathrm{C}$ to $1^{\circ} \mathrm{C}$, especially in fruit from the first harvest and those treated $3 \mathrm{~d}$ after harvest (Table 5). Apples not treated with 1MCP had less ethylene production after 6 months than 3 months of air storage, suggesting that these fruit were post-climacteric. Fruit treated with $1000 \mathrm{ppb}$ l-MCP showed a slower increase in ethylene production than those treated with $625 \mathrm{ppb}$ during $14 \mathrm{~d}$ at $22{ }^{\circ} \mathrm{C}$ after 3 and 6 months of air storage at $0{ }^{\circ} \mathrm{C}$ to $1^{\circ} \mathrm{C}$ 
Table 5. Ethylene production of 'McIntosh' apples from three harvests treated with 1-methylcyclopropene (1-MCP; 0,625 , or $\left.1000 \mathrm{ppb}^{\mathrm{z}}\right) 3,7$, or $10 \mathrm{~d}$ after harvest, and stored for 3 or 6 months in air at $0{ }^{\circ} \mathrm{C}$ to $1{ }^{\circ} \mathrm{C}\left(32.0^{\circ} \mathrm{F}-33.8^{\circ} \mathrm{F}\right)$. The highest levels of significant effects (interactive) are presented and the data are the means of two evaluations after storage $\left[1\right.$ and $7 \mathrm{~d}$ at $\left.22^{\circ} \mathrm{C}\left(71.6^{\circ} \mathrm{F}\right)\right]$.

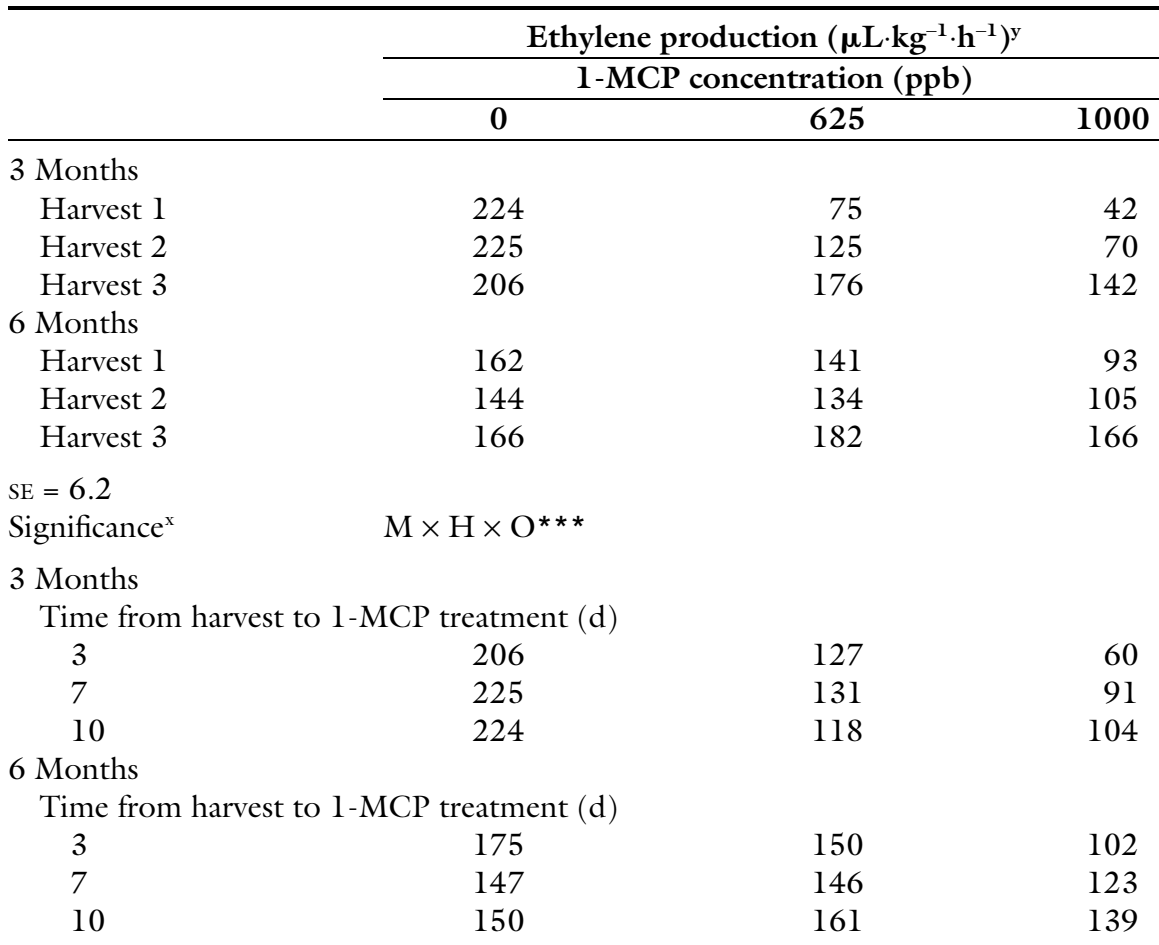

$\mathrm{SE}=6.2$

Significance $^{x}$

$\mathrm{T} \times \mathrm{M} \times \mathrm{O}^{*}$

${ }^{\mathrm{z}} 1 \mathrm{ppb}=1 \mathrm{~nL} \cdot \mathrm{L}^{-1}$.

${ }^{\mathrm{y}} \mathrm{l} \mu \mathrm{L} \cdot \mathrm{kg}^{-1}=1 \mathrm{ppm}$

${ }^{* *}, * * *$ Significant at $P<0.05$ or $P<0.001$, respectively, where $\mathrm{T}=$ treatment time, $\mathrm{M}=1-\mathrm{MCP}$ concentration, $\mathrm{H}=$ harvest, and $\mathrm{O}=$ months.

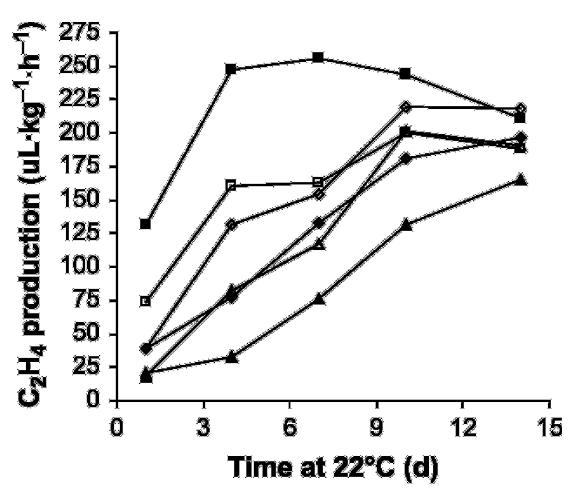

$\rightarrow-3$ months $0 \mathrm{ppb} \quad \longrightarrow 3$ months $625 \mathrm{ppb}$

$\rightarrow-3$ months $1000 \mathrm{ppb} \rightarrow-6$ months 0 ppb

$\multimap 6$ months $625 \mathrm{ppb} \triangle-6$ months $1000 \mathrm{ppb}$

Fig. 1. Ethylene production of 'McIntosh' apples treated with 0,625 , or $1000 \mathrm{ppb}$ 1-methylcyclopropene (1-MCP), stored for 3 and 6 months in air at $0{ }^{\circ} \mathrm{C}$ to $1{ }^{\circ} \mathrm{C}$ $\left(32.0^{\circ} \mathrm{F}-33.8^{\circ} \mathrm{F}\right)$, and held $14 \mathrm{~d}$ at $22{ }^{\circ} \mathrm{C}$ $\left(71.6^{\circ} \mathrm{F}\right)$. Data are the means of three harvests and three 1-MCP treatment times $(3,7$, and $10 \mathrm{~d}$ after harvest). The interaction of $1-\mathrm{MCP} \times$ Month $\times$ Day is significant at $P<0.001(\mathrm{sE}=7.98)$. $1 \mathrm{ppb}=1 \mathrm{~nL} \cdot \mathrm{L}^{-1}, 1 \mu \mathrm{L} \cdot \mathrm{kg}^{-1}=1 \mathrm{ppm}$.
(Fig. 1). Also during this time, respiration (measured as $\mathrm{CO}_{2}$ production) was the lowest in 'McIntosh' apples treated with $1000 \mathrm{ppb} 1-\mathrm{MCP} 3 \mathrm{~d}$ after harvest, but fruit treated with 625 ppb also exhibited lower respiration than those not treated (Fig. 2). Similar patterns were observed in apples from CA storage, but the differences in $\mathrm{CO}_{2}$ production were not as great (Fig. 3).

1-MCP blocks the ethylene receptors and consequently prevents the effects of ethylene, such as those associated with fruit ripening. Therefore, reduced ethylene production in fruit would be an expected response to 1-MCP treatment, and this has been confirmed for several apple cultivars under various conditions (DeEll et al., 2005a, 2005b, 2007; DeLong et al., 2004; Fan et al., 1999a; Rupasinghe et al., 2000; Watkins et al., 2000; Watkins and Nock, 2005). In this study, ethylene production increased with time at $22{ }^{\circ} \mathrm{C}$, suggesting that the effect of
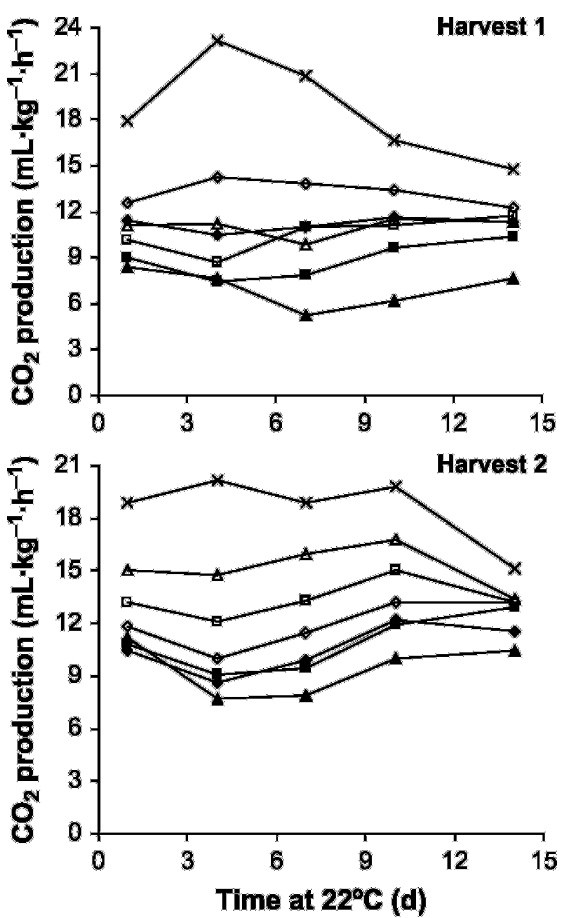

\begin{tabular}{|ll|}
$*-0 \mathrm{ppb}$ & $\varangle 3 \mathrm{~d} 625 \mathrm{ppb}$ \\
$-3 \mathrm{~d} 1000 \mathrm{ppb}$ & $\square-7 \mathrm{~d} 625 \mathrm{ppb}$ \\
$-7 \mathrm{~d} 1000 \mathrm{ppb}$ & $-10 \mathrm{~d} 625 \mathrm{ppb}$ \\
$-10 \mathrm{~d} 1000 \mathrm{ppb}$ & \\
\hline
\end{tabular}

Fig. 2. Carbon dioxide $\left(\mathrm{CO}_{2}\right)$ production of 'McIntosh' apples from Harvests 1 and 2 treated 3, 7, or $10 \mathrm{~d}$ after harvest with 0,625 , or $1000 \mathrm{ppb}$ 1-methylcyclopropene (1-MCP), stored for 3 and 6 months (data combined) in air at $0{ }^{\circ} \mathrm{C}$ to $1^{\circ} \mathrm{C}(32.0$ ${ }^{\circ} \mathrm{F}-33.8{ }^{\circ} \mathrm{F}$ ), and held $14 \mathrm{~d}$ at $22^{\circ} \mathrm{C}$ $\left(71.6^{\circ} \mathrm{F}\right)$. The interaction of Harvest $\times$ Treatment $\times 1-M C P \times$ Day is significant at $P<0.05(\mathrm{sE}=0.73) .1 \mathrm{ppb}=1$ $\mathrm{nL} \cdot \mathrm{L}^{-1}, 1 \mathrm{~mL} \cdot \mathrm{kg}^{-1}=1000 \mathrm{ppm}$.

1-MCP may be temporary and/or other receptor sites may be synthesized.

Storage disorders were most prevalent in 'McIntosh' apples stored for 6 months in air at $0^{\circ} \mathrm{C}$ to $1{ }^{\circ} \mathrm{C}$ and fruit from the first harvest treated with 1-MCP $3 \mathrm{~d}$ after harvest developed the fewest (Table 6). Extensive flesh browning developed in fruit from Harvest 3, but there was lower incidence with 1-MCP treatment $3 \mathrm{~d}$ after harvest (75\% vs. $50 \%)$. These results are in contrast to previous studies where the incidence of internal browning in 'Empire' and 'Delicious' apples was unaffected by 1-MCP treatment (DeEll et al., 2007; Watkins and Nock, 2005). Watkins and Nock (2005) also found that flesh browning in 'Empire' apples increased dramatically in late harvested fruit and it was unaffected by 1-MCP, 

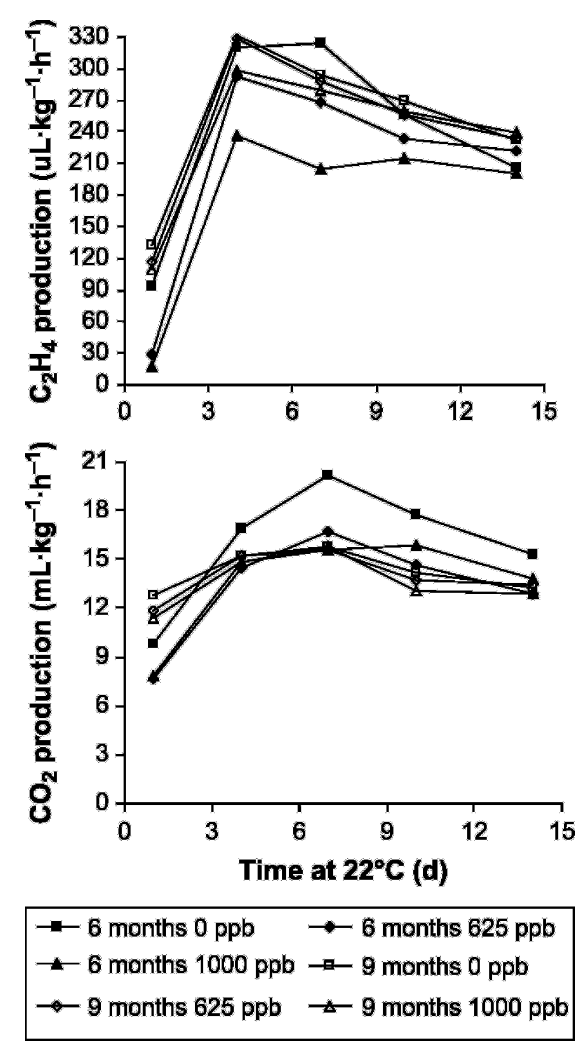

Fig. 3. Ethylene and carbon dioxide $\left(\mathrm{CO}_{2}\right)$ production of 'McIntosh' apples treated with 0,625 , or $1000 \mathrm{ppb} 1$ methylcyclopropene (1-MCP), stored for 6 and 9 months in controlled atmosphere (CA) at $3^{\circ} \mathrm{C}\left(37.4^{\circ} \mathrm{F}\right)$, and held $14 \mathrm{~d}$ at $22^{\circ} \mathrm{C}\left(71.6^{\circ} \mathrm{F}\right)$. Data are the means of three harvests and three 1-MCP treatment times $(3,7$, and $10 \mathrm{~d}$ after harvest). The interaction of 1 MCP $\times$ Month $\times$ Day is significant at $P<0.01(\mathrm{SE}=0.34) .1 \mathrm{ppb}=1 \mathrm{~nL} \cdot \mathrm{L}^{-1}$, $1 \mu \mathrm{L} \cdot \mathrm{kg}^{-1}=1 \mathrm{ppm}, 1 \mathrm{~mL} \cdot \mathrm{kg}^{-1}=1000$ ppm.

irrespective of delays before treatment (up to $8 \mathrm{~d}$ ). The incidence of flesh browning did not increase with more time between harvest and 1-MCP treatment in this study, nor was there any effect of 1-MCP concentration (Table 6). There was little effect of time at $22{ }^{\circ} \mathrm{C}$ after storage on flesh browning except in apples from Harvest 2 where the disorder was only present after $7 \mathrm{~d}$ at $22^{\circ} \mathrm{C}$.

Substantial core browning and superficial scald developed after $7 \mathrm{~d}$ at $22{ }^{\circ} \mathrm{C}$ and there was greater incidence of both disorders in apples from Harvest 3 (Table 6). Typically, superficial scald is more prevalent in earlier harvests (Emongor et al., 1994) and core browning is reduced with advanced maturity (Meheriuk et al., 1994). 1-MCP reduced the

Table 6. Incidence of flesh browning, core browning, and superficial scald in 'McIntosh' apples from three harvests treated with 1-methylcyclopropene (1-MCP; 0, 625, or $\left.1000 \mathrm{ppb}^{\mathrm{z}}\right) 3,7$, or $10 \mathrm{~d}$ after harvest, stored for 6 months in air at $0{ }^{\circ} \mathrm{C}$ to $1^{\circ} \mathrm{C}\left(32.0^{\circ} \mathrm{F}-33.8^{\circ} \mathrm{F}\right)$, and held 1 or $7 \mathrm{~d}$ at $22{ }^{\circ} \mathrm{C}\left(71.6^{\circ} \mathrm{F}\right)$.

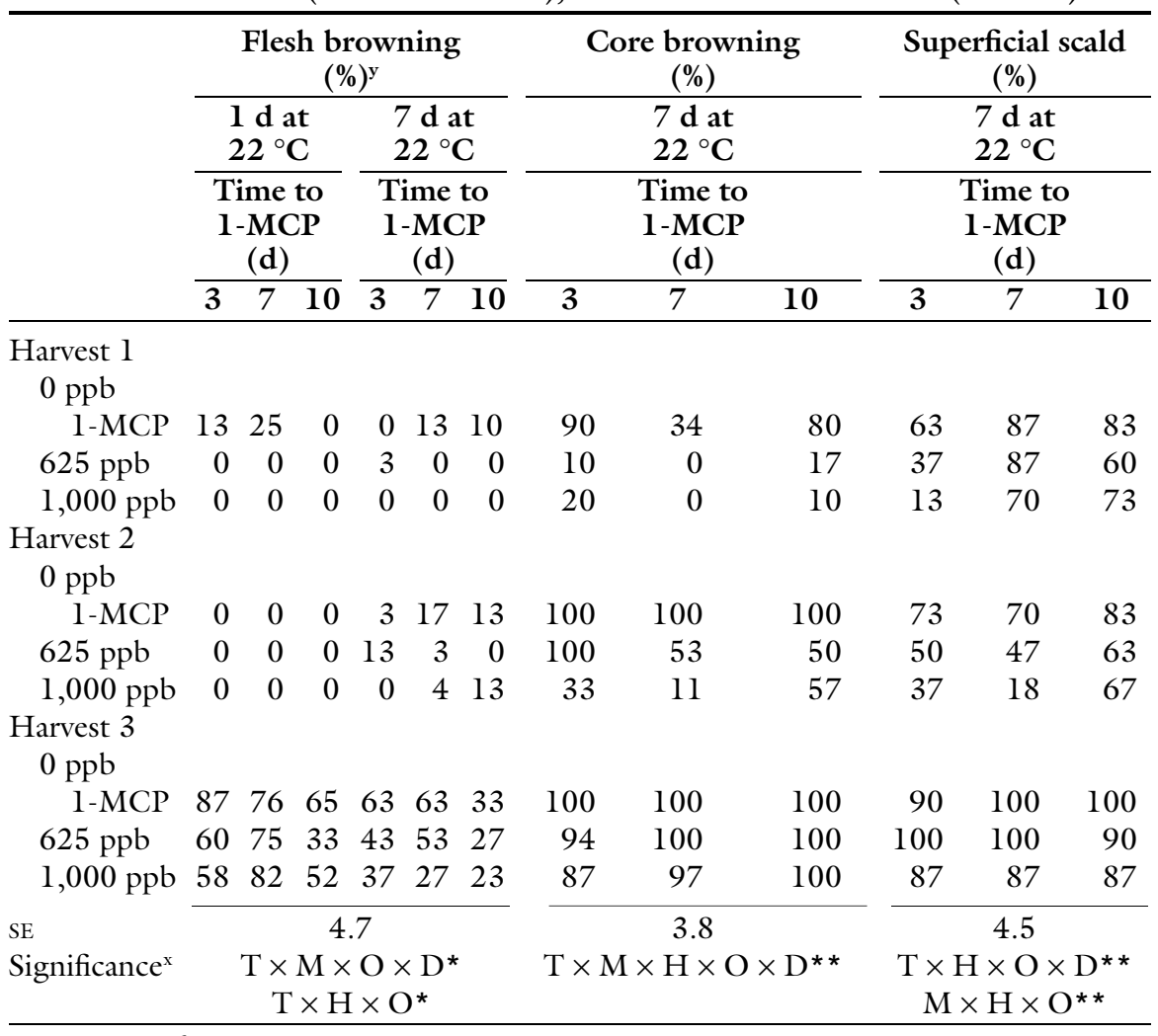

${ }^{2} 1 \mathrm{ppb}=1 \mathrm{~nL} \cdot \mathrm{L}^{-1}$.

yercentage data were transformed to angles $\left(\mathrm{Y}=\sin ^{-1} \sqrt{\% 100}\right)$ and back-transformed to percentage for presentation $\left[\%=100 \times(\sin Y)^{2}\right]$

${ }^{* *},{ }^{* *}$ Significant at $P<0.05$ or $P<0.01$, respectively, where $\mathrm{T}=$ treatment time, $\mathrm{M}=1$-MCP concentration, $\mathrm{H}=$ harvest, $\mathrm{O}=$ months, and $\mathrm{D}=$ days at $22{ }^{\circ} \mathrm{C}$.

incidence of core browning and superficial scald, albeit neither disorder was completely controlled (Table 6). DeLong et al. (2004) also found that $1-M C P$ reduced the incidence of core browning and superficial scald in 'Summerland McIntosh' stored for 6 or 9 months in air at $3{ }^{\circ} \mathrm{C}$ plus $21 \mathrm{~d}$ at $20{ }^{\circ} \mathrm{C}$. However, under these same conditions, l-MCP reduced the incidence of core browning in 'Redmax McIntosh' after 6 months, but not after 9 months. There was little effect of 1-MCP concentration or time between harvest and treatment on disorders, except that apples from Harvest 2 treated 3 or $7 \mathrm{~d}$ after harvest had lower incidence of core browning with 1000 than $625 \mathrm{ppb}$ (Table 6). Watkins and Nock (2005) found that superficial scald was reduced by 1-MCP in 'Cortland' and 'Delicious' apples, but there was no effect of delay before treatment (up to $8 \mathrm{~d}$ ). 1-MCP has also been shown to control superficial scald in CA-stored 'McIntosh' from four orchards in Maine (Moran, 2006).

Some senescent breakdown was also observed after 6 months of air storage at $0{ }^{\circ} \mathrm{C}$ to $1{ }^{\circ} \mathrm{C}$ plus $7 \mathrm{~d}$ at $22{ }^{\circ} \mathrm{C}$, with lower incidence in the 1 MCP treated apples $(29 \%$ vs. $13 \%)$. A similar reduction in senescent breakdown has been shown in 1MCP treated 'Summerland McIntosh' after 9 months in air storage at $3{ }^{\circ} \mathrm{C}$ plus $21 \mathrm{~d}$ at $20^{\circ} \mathrm{C}$ (DeLong et al., 2004). The incidence of senescent breakdown in 'Cortland' apples was found to increase with increasing delay between harvest and 1-MCP treatment (Watkins and Nock, 2005). However, the delay in l-MCP treatment in this study had no consistent effect on senescent breakdown in 'McIntosh' apples (data not presented).

'McIntosh' apples stored for 3 months in air at $0{ }^{\circ} \mathrm{C}$ to $1{ }^{\circ} \mathrm{C}$ developed very few disorders $(<2 \%)$. Similarly, few internal disorders $(<1 \%$ flesh and core browning) were found 
in 'McIntosh' apples stored in CA at 3 ${ }^{\circ} \mathrm{C}$. Superficial scald developed in CAstored fruit, with an incidence of $5 \%$ and $8 \%$ after 6 and 9 months, respectively, plus $7 \mathrm{~d}$ at $22{ }^{\circ} \mathrm{C}$; however, there was no consistent effect of 1 MCP treatment, which was likely due to the low incidence observed. The fact that scald was observed in apples drenched with diphenylamine suggests that the concentration used in this study (1000 ppm a.i.) was not adequate for complete control during long-term storage. External $\mathrm{CO}_{2}$ injury is often found in 'McIntosh' and 'Empire' apples treated with 1MCP and stored in CA (DeEll et al., 2003; Fawbush et al., 2008). However, all fruit in this study were drenched with the antioxidant diphenylamine, which has been shown to control $\mathrm{CO}_{2}$ injury in apples (Watkins et al., 1997), and thus no such injury was observed.

The research described here has provided the basis for the Canadian SmartFresh $^{\text {SM }}$ label and the recommendation by AgroFresh that 'McIntosh' apples should be treated within $3 \mathrm{~d}$ of harvest (AgroFresh Inc., 2007). The importance of minimizing 1-MCP treatment delays becomes greater as storage time increases and apples are pushed to their maximum life span. 1-MCP concentrations less than $1000 \mathrm{ppb}$ due to application methods can also reduce the beneficial effects in 'McIntosh' fruit, especially with treatment delays or longterm storage periods. Therefore, storage operators should take care as to when and how their apples are treated with 1-MCP.

\section{Literature cited}

AgroFresh Inc. 2007. The SmartFresh ${ }^{\mathrm{SM}}$ quality system for apples: Apple use recommendations. AgroFresh Inc., Spring House, PA.

Bai, J., E.A. Baldwin, K.L. Goodner, J.P. Mattheis, and J.K. Brecht. 2005. Response of four apple cultivars to 1- methylcyclopropene treatment and controlled atmosphere storage. HortScience 40:1534-1538.

Blankenship, S.M. and J.M. Dole. 2003. 1-Methylcyclopropene: A review. Postharvest Biol. Technol. 28:1-25.

Blanpied, G.D. and K. Silsby. 1992. Predicting harvest date windows for apples. Cornell Univ. Info. Bul. 221.

DeEll, J.R., J.T. Ayres, and D.P. Murr. 2007. 1-Methylcyclopropene influences 'Empire' and 'Delicious' apple quality during long-term commercial storage. HortTechnology 17:46-51.

DeEll, J.R., D.P. Murr, M.D. Porteous, and V.R. Rupasinghe. 2002. Influence of temperature and duration of 1-methylcyclopropene (1-MCP) treatment on apple quality. Postharvest Biol. Technol. 24: 349-353.

DeEll, J.R., D.P. Murr, L. Wiley, and M.D. Porteous. 2003. 1-Methylcyclopropene (1-MCP) increases $\mathrm{CO}_{2}$ injury in apples. Acta Hort. 600:277-280.

DeEll, J.R., D.P. Murr, L. Wiley, and R. Mueller. 2005a. Interactions of 1-MCP and low oxygen CA storage on apple quality. Acta Hort. 682:941-948.

DeEll, J.R., D.P. Murr, R. Mueller, L. Wiley, and M.D. Porteous. 2005b. Influence of 1-methylcyclopropene (1-MCP), diphenylamine (DPA), and $\mathrm{CO}_{2}$ concentration during storage on 'Empire' apple quality. Postharvest Biol. Technol. 38: $1-8$.

DeLong, J.M., R.K. Prange, and P.A. Harrison. 2004. The influence of 1-methylcyclopropene on 'Cortland' and 'McIntosh' apple quality following long-term storage. HortScience 39:1062-1065.

Emongor, V.E., D.P. Murr, and E.C. Lougheed. 1994. Preharvest factors that predispose apples to superficial scald. Postharvest Biol. Technol. 4:289-300.

Fan, X., S.M. Blankenship, and J.P. Mattheis. 1999a. 1-Methylcyclopropene inhibits apple ripening. J. Amer. Soc. Hort. Sci. 124:690-695.

Fan, X., J.P. Mattheis, and S. Blankenship. 1999b. Development of apple superficial scald, soft scald, core flush, and greasiness is reduced by MCP. J. Agr. Food Chem. 47:3063-3068.

Fawbush, F., J.F. Nock, and C.B. Watkins. 2008. External carbon dioxide injury and 1-methylcyclopropene (1-MCP) in the 'Empire' apple. Postharvest Biol. Technol. 48:92-98.

Meheriuk, M., R.K. Prange, P.D. Lidster, and S.W. Porritt. 1994. Postharvest disorders of apples and pears. Agr. AgriFood Canada Publ. 1737/E.

Moran, R.E. 2006. Maintaining fruit firmness of 'McIntosh' and 'Cortland' apples with aminoethoxyvinylglycine and 1 -methylcyclopropene during storage. HortTechnology 16:513-516.

Payne, R. 2000. Genstat release 4.2, reference manuals. Lawes Agricultural Trust, Rothamsted Experimental Station, Harpenden, UK.

Rupasinghe, H.P.V., D.P. Murr, G. Paliyath, and L. Skog. 2000. Inhibitory effect of 1-MCP on ripening and superficial scald development in 'McIntosh' and 'Delicious' apples. J. Hort. Sci. Biotechnol. 75:271-276.

Watkins, C.B. 2006. The use of 1-methylcyclopropene (1-MCP) on fruits and vegetables. Biotechnol. Adv. 24:389-409.

Watkins, C.B. 2007. The effect of 1-MCP on the development of physiological storage disorders in horticultural crops. Stewart Postharvest Rev. 2:11.

Watkins, C.B. and J.F. Nock. 2005. Effects of delays between harvest and 1methylcyclopropene treatment, and temperature during treatment, on ripening of air-stored and controlled-atmospherestored apples. HortScience 40:20962101 .

Watkins, C.B., J.F. Nock, and B.D. Whitaker. 2000. Responses of early, mid and late season apple cultivars to postharvest application of 1-methylcyclopropene (1MCP) under air and controlled atmosphere storage conditions. Postharvest Biol. Technol. 19:17-32.

Watkins, C.B., K.J. Silsby, and M.C. Goffinet. 1997. Controlled atmosphere and antioxidant effects on external $\mathrm{CO}_{2}$ injury of 'Empire' apples. HortScience 32:1242-1246. 